\title{
STRUCTURAL APPROACH TO THE STUDY OF MEANING (ON THE MATERIAL OF ADJECTIVES IN MODERN UKRAINIAN)
}

\section{Fabian M. P.}

\section{INTRODUCTION}

In recent years, the problem of meaning has been explored in all its manifold aspects. Philosophers, philologists, psychologists, anthropologists, students of literature and arts, even economists and scientists working in different spheres of human activities have joined in the debate. Meaning seems at once the most common feature of language and the most obscure aspect to study. It is obvious because it is what we use language for - to communicate with each other, share knowledge, experience, give information, advice, warn about something, etc. as well as to convey what we mean effectively. But the steps in understanding what has been said to us in a language we speak are so rapid, so transparent, that we are little conscious of both principles and knowledge which underlie this communicative ability.

Two major branches of linguistics are specially concerned with words: etymology, the study of word origins, and semantics, the study of word meanings. Of the two, the former is an old-established discipline whereas the latter is comparatively new. The need for an independent science of meaning was not felt until the XIXth century when it emerged as an important part of linguistics and received its modern name. Two main factors played a decisive part in the emergence of semantics: the rise of comparative philology, more generally, the scientific linguistics in its modern sense, and the influence of the Romantic Movement in literature. The Romantics had an intense interest in words, and they were fascinated by the strange as well as mysterious potencies of different words. According to the history of semantics, it covers three distinct periods: the first which lasted approximately half a century, was described as the "underground period" of semantics when German scholars welcomed Reisig's initiative to pay attention to meaning rather than form as the latter prevailed in philological studies of that time. The second period in the history of semantics began in the early 1880s and lasted for almost half a century. This time it was due to Bréal who outlined the programme of the new science and named it the way it is used at present. The abovementioned philologists regarded semantics as a purely historical 
study, and so most semanticists considered that their prime task was to study changes of meaning, their causes, to classify them according to various (psychological, logical, etc.) criteria, and, if possible, to formulate both general laws and tendencies underlying them. Since the turn of the century, certain fundamental changes took place in General linguistics: F.de Saussure's innovative approach to the study of language which treated the latter as an organized totality comprised of various interdependent elements which, in their turn, derive their significance from the system as a whole. He compared language to a game of chess where no unit can be added, removed or displaced without altering the entire system of relations on the chessboard. This vision of language as a system of interdependent elements lies at the root of what is called structural linguistics nowadays. Trier's work on terms of knowledge in German was the first serious attempt to introduce F.de Saussure's principles into semantics. The new semantics differed much from the traditional approach: it focused on the study of the inner structure of the vocabulary, shifted from general principles to the study of particular languages.

Contemporary semantics is a self-contained and integral department of philology. It makes use of achievements obtained from related as well as non-related branches of sciences. Together with traditional applications of the study of meaning, the present research introduces structuralist conception of meaning which makes possible to use the structural approach to the study of adjectives in modern Ukrainian.

\section{Lexical semantics of adjectives in modern Ukrainian}

Semantics, the theory of meaning, is the youngest branch of modern linguistics. Three sets of problems confront the semanticist at the very outset of his work: the terminology and the very name of his science; its relation to some extra-linguistic pursuits of the same name; finally, the place to which it is entitled in the general structure of modern linguistics ${ }^{1}$. Structural semantics is mainly concerned with word semantics, and it is not confined to isolated language units, but focuses on lexical fields and paradigmatic semantic relations between them. Lexical semantics, especially the ways of its study, belongs to less investigated issues of modern linguistics, which are open to thought and discussion, and need their further in - depth study. Attempts have been made to describe and analyze different lexical structures into which the words are organized. These inquiries are conducted at the levels of single words, conceptual spheres and vocabulary as a whole. Our approach to the

${ }^{1}$ Ullmann S. The Principles of Semantics. Glasgow: Jackson \& Co, Oxford: Basil Blackwell, 1957. P. 4. 
study of lexical semantics is an attempt to combine the first two levels, on the basis of which the entire vocabulary of a language can be studied. There are many different approaches to the way in which meaning in language is studied, but what we shall be concerned with is the semantic classification of lexis, and it is the author's attempt to shed light on lexical semantics' study, combining pure linguistic with mathematical methods. Put together, they make up the formalized basis for the semantic classification of lexis, with the help of which nearly all groups of lexis can be studied. Significantly, these groups can be revealed and thoroughly analyzed not only within one language system, but also in comparison with other both related and non - related ones.

The central idea of our structural approach to the study of meaning is that language has to be treated as a system of interrelated and hierarchically organized elements which, in their turn, also form a definite system. As Geeraerts D. puts it, if you focus the study of linguistic meaning on individual items, then you will automatically be interested in the different meanings items may have, and in the relations that exist among those meanings $^{2}$. The Ukrainian language as a system of signs, has its own properties and principles which determine the functioning of these signs. The latter are the part of the language system, and we describe them within it, and also in their relationships to other signs in the system under study. Moreover, the vocabulary of the language is a network of expressions that are mutually related by all kinds of semantic links. If we consider language as a system of signs, or, following F.de Saussure, as a structure of interdependent elements, then we can distinguish at least two types of structure in the lexicon, namely external (to the word) and internal (to the meaning). The term "lexicon" is used by Lipka L. in two senses that are not always sharply distinguished: a) for a metalinguistic level, or a subcomponent in a linguistic model (basically compatible with a variety of theories of language); and b) in the sense of vocabulary as seen from a systematic, synchronic point of view ${ }^{3}$.

Adjectives make up the class of inflected words. They show the extent or degree to which the quality they express applies to the word they modify, especially in relation to other things or conditions of the same kind. Our research deals with structural approach to the study of lexical semantics of adjectives denoting the property of being respected. All the lexical units in question make up a definite system which consists of elements (adjectives themselves) that are hierarchically placed within this system. Moreover, they are closely interrelated and interconnected, and the same concerns their meanings. Semantics of adjectives is studied with the

\footnotetext{
${ }^{2}$ Geeraerts D. Theories of Lexical Semantics. Oxford: Oxford University Press, 2010.P.50.

${ }^{3}$ Lipka L. English Lexicology: Lexical Structure, Word Semantics and Word-formation. Tübingen: Narr, 2002. P. 13.
} 
help of componential analysis which remains one of the most efficient means of the lexical meaning study. Much attention is paid to the way lexical meanings of the adjectives denoting the properties of being respected in Ukrainian are structured with the help of componential analysis as well as mathematical and statistical methods.

Great achievements of both mathematical and structural linguistics made it possible to create a formalized basis for the semantic classification of lexis, according to which language is treated as a system of a certain structure where each lexical unit occupies its definite place, and stands in certain relationships to other lexical units. Having introduced formal, purely linguistic criterion- belonging of the words to a definite part of speech - the adjective, an in-depth study of their semantics is carried out on the basis of the continuous analysis of the Ukrainian explanatory dictionary ${ }^{4}$. Methodology of collecting, classifying and analyzing our language material lies in the following successive steps:

- from the biggest Ukrainian explanatory dictionary, the adjectives, the lexical meanings of which contain the properties of being respected, esteemed, honoured, etc. are selected;

- on the basis of the obtained lists of words, the card indices are piled;

- both common and distinctive qualitative and quantitative analyses of the words under study as well as their semantics are made.

The adjectives under study denote classes of qualities bound together by some common element (the property of being respected). We agree with Ullmann S. that the words are never completely homogeneous: even the simplest and the most monolithic have a number of different facets depending on the context and situation in which they are used, and also on the personality of the speaker using them ${ }^{5}$.

37 adjectives are widely used in Ukrainian to describe qualities of people deserving respect due to their certain merits and everyday life activities. Here belong the lexical units поважний, сприятливий, обачний, ввічливий (увічливий), маститий, дорогочінний, вельмишановний, величавий, статечний, вашецький (вамеський), поважаний, святий, останній, посмертний, тречний, побожний, земний, уклінний, почесний, чесний, шанобливий, величний, високошановний, поштивий (почтивий), превелебний, славетний, чемний, преславний, величальний, священний, шановний, гідний, високоповажаний, високоповажний, благоговійний, святобливий, добрий.

${ }^{4}$ Словник української мови: В 11-ти т. Київ: Наукова думка,1970-1980.

${ }^{5}$ Ullmann S. Semantics. An Introduction to the Science of Meaning. Oxford: The Alden Press Basil Blackwell,1962. P. 124. 
Each of these adjectives possesses the following semantic characteristics: поважний - 1. Який заслуговує, вартий поваги; який користується повагою.// Відомий своєю роботою, заслугами, посадою. // Немолодий. // Уживається при звертанні. 2. Який відзначається вдумливістю, серйозністю. // Сповнений поваги, серйозності; який виражає повагу, серйозність, вдумливість. 3. Сповнений гідності; величний. // Урочистий. 4. Авторитетний, значний. 5. Серйозний за своїм змістом, характером, темою. 6. Який має неабияке значення. Важливий, значний.// Який заслуговує особливої уваги внаслідок своєї важливості, значимості.// Який може бути прийнятий до уваги; достатній для виправдання чогонебудь. 7. Повільний, не швидкий.// Протяжний, задумливий (про пісню, мелодію). 8. Діал. Великий (розміром, кількістю). У поважному стані - вагітна. The word сприятливий means який позитивно впливає на що-небудь, створює відповідні умови для здійснення, виконання і т. ін. чогось. // Потрібний, необхідний для чого-небудь; належний. // Зручний для чого-небудь. // У якому виражається прихильність, шанобливе ставлення, повага до кого-небудь. The adjective обачний expresses 1. Який діє розумно, спокійно, непередбачливо.// Який виявляє обережність у своїх діях, не наражається на неприємність, небезпеку; обережний. 2. Який зважає на інтереси, запити інших, виявляє повагу до них; чемний, уважний.

The next lexical units meriting our attention are ввічливий (увічливий) and маститий. The first means який дотримується правил пристойності, виявляє уважність, люб'язність; чемний. // В якому проявляється уважність, люб'язність, and the latter - який заслужив загальну повагу, визнання своєю багаторічною плідною діяльністю (про діячів науки, мистецтва тощо).

Among the synonyms belonging to the group of adjectives under study one can mention the following ones: вельмишановний - Гідний великої поваги (узвичаєна форма ввічливості при звертанні до когось або при згадуванні когось); величавий - 1. Який своїми розмірами, виглядом або діями, вчинками викликає почуття поваги, певної урочистості. // сповнений урочистості. 2. Який тримається 3 великою гідністю, гордовитістю; вашещький (вашеський) - Гідний поваги; шановний. // ірон. Гордовитий, пихатий; поважаний - 1. Дієпр. акт.теп. ч. до поважати 1. 2. Якого поважають, який користується повагою в когонебудь.// Уживається як формула ввічливості при звертанні; благоговійний - Сповнений найщирішої поваги, шани; безмежно відданий; побожний; гідний - 1. Який заслуговує або вартий чогонебудь. 2. Який відповідає вимогам часу, обставинам; належний.// Цілком відповідний у даному випадку; потрібний. 3. Такий, що має 
високі позитивні якості; достойний. 4. діал. Шановний; величальний Який вшановує, звеличує кого-небудь; шановний - Якого поважають, шанують. // Уживається як складова частина ввічливого звертання. // Уживається для вираження фамільярної оцінки кого-, чого- небудь. Той, кого поважають, шанують (перев. у звертанні); чемний Шанобливо ввічливий до людей. // В якому виявляється ввічливість, уважність, люб'язність; славетний -1. Який має широку славу, популярність; знаменитий.// Добре відомий багатьом, усім. // Прославлений героїчними ділами, подвигами і т. ін. // Пов'язаний 3 героїчними ділами, подвигами. // Який прославляє кого-небудь. 2. Гідний поваги, пошани; преславний - 1. Який надзвичайно уславив себе чим-небудь, достойний великої слави. // Відомий дуже широким колам людей; славнозвісний. // Який приносить, приніс комусь велику славу. 2. Який викликає велику симпатію; дуже гарний, приємний. Який викликає велику симпатію; дуже гарний, приємний.// Який відзначається, вирізняється чимсь особливим. 3. Вельмишановний (при шанобливому звертанні до кого-небудь).// у знач. Преславний, преславні. Уживається у звертанні до високоповажних осіб; поштивий (почтивий) - 1. Який виявляє повагу до кого-небудь; чемний, ввічливий. 2. Гідний пошани, поваги; високошановний - Гідний великої пошани, поваги (вживається при офіційно-ввічливому звертанні до кого-небудь або в розмові про когось); шанобливий - Сповнений глибокої поваги, пошани до кого-, чого-небудь. // Який виявляє глибоку повагу, пошану до кого-небудь. // Сповнений виразу глибокої поваги, пошани до кого-, чого-небудь; уклінний - Який виражає пошану; шанобливий. // Який виражає покору, смиренність; тречний Шанобливо ввічливий у поводженні з людьми; чемний. // Який виражає шанобливість, увічливість.

While making lexico-semantic analysis of our language material, we have come across the words which are absolute synonyms and fully coincide in their meanings: високоповажаний - Те саме, що високошановний and високоповажний - Те саме, що високошановний. It means that due to this semantic specificity they acquire the meaning of the adjective високошановний - Гідний великої пошани, поваги (вживається при офіційноввічливому звертанні до кого-небудь або в розмові про когось). То bе respected, one should have high standards and good personal qualities such as fairness, honesty, responsibility for other people as well as for their deeds, etc. Such a variety of semantic connotations is revealed by the inner structures of the adjectives чесний, почесний and статечний. The first in this line is the lexical unit чесний - 1. Який відзначається високими моральними якостями. // не здатний украсти що-небудь, не схильний до крадіжки. // 
Який виражає правдивість, прямоту характеру, відвертість (про обличчя, погляд і т. ін.). // Властивий людині, яка має високі моральні якості. // Який старанно, ретельно виконує свої обов'язки; сумлінний. // Той (та), що має високі моральні якості, правдивий, відвертий. 2. Сумісний 3 поняттям честі, чесності, 3 правилами честі. // Який випливає з сумлінного ставлення до своїх обов'язків. // Зароблений без обману, своєю сумлінною працею. 3. Який не заслуговує ніякої догани; порядний, нічим не заплямований. // Яка зберігає свою жіночу честь, дівочу невинність, цнотливість. 4. Шановний, поважний, сповнений честі (у 2 знач.). // Який заслуговує на високу повагу, пошану. 5. Шановний за святістю і релігійністю.// При звертанні до духовної особи. The second in the line is the word почесний - 1. Гідний поваги, пошани. // Який користується повагою, пошаною. 2. Призначений для вияву поваги, пошани. // Такий, що надається на знак поваги, пошани. // Такий, що обирається на знак поваги, пошани. 3. Який робить честь кому-небудь. // Честь або гідність якого не принижено. The third to focus on is the adjective статечний - 1. Розсудливо-серйозний, розважливий у вчинках; з позитивними якостями (про людину); поважний. // Властивий розсудливо-серйозній, поважній людині, характерний для такої людини; сповнений гідності, поважності. 2. Який справляє враження, привертає увагу своєю зовнішністю; показний. 3. Який має достаток; заможний. 4. Немолодий, середнього віку; літній. 5. Який справляє позитивне враження, відзначається порядністю; пристойний, добропорядний. 6. Який заслуговує поваги своїм значенням, достоїнством і т.п.

There are adjectives in our language material semantics of which is closely connected with the characteristics of people's qualities directed towards religious worship, reverence, God, devotion, religious rituals, ceremony, church, religion, cross, belief, piety and the like. To such lexical units belong: святобливий - 1. Який вірить у бога й старанно виконує всі релігійні обряди; побожний. // Який виражає побожність. 2. Сповнений найщирішої поваги, шани; священний - 1. Пов'язаний з релігією, церквою. // Який має божественну силу. // Який є предметом релігійного поклоніння. 2. Який ведуть, здійснюють в інтересах релігії. 3. Який глибоко шанують; дорогий, заповітний. // Те, що глибоко шанують. // Якого мають дотримуватися всі, обов'язковий для всіх. 4. На який не можна посягати. 5. Високий, благородний. // Особливо почесний. // Метою якого є воля, визволення, мир і т. ін. (про боротьбу, війну тощо); святий - 1. Пов'язаний з релігією, богом, наділений божественною силою. // Перейнятий божественною силою. // Уживається як постійний епітет до слів, пов'язаних із місцями або предметами релігійного поклоніння. // Освячений. // Уживається при вираженні переляку, подиву, обурення. 
2. Який, за християнською релігією, провів життя в служінні богові й якого після смерті церква визнала небесним заступником віруючих. // Праведний, непорочний, угодний богові. // Люди, які все життя присвятили служінню богові й після смерті визнані церквою небесними заступниками віруючих. // Те саме, що ікони. 3. Уживається як постійний епітет до свят, визначених релігією. 4. Морально чистий, благородний, бездоганний у житті, поведінці тощо. // Не винний у чомунебудь, перед кимсь; безгрішний. // Людина, яка не винна ні в чому, ні перед ким. // Чистий, благородний. // Який виражає чистоту, благородство (про очі, обличчя і т. ін.). // Освячений високою метою. // Особливо почесний. 5. Який глибоко шанують; дорогий, заповітний. // Те, що глибоко шанують.// Непорушний, непохитний.//кого мають дотримуватися всі, обов'язковий для всіх. // Звичний, природний, особливо бажаний.

Some adjectives under study have a big communicative potential, and they are frequently used in both verbal and non-verbal communication. The latter is closely connected with a man of worship, the figure of bishop, various forms of addressing people, expressions of cult, religion, churchservice, homage, a particular system of religious worship, commemoration, etc. Here belong the adjectives превелебний - 1. Титул єпископа. 2. Гідний великої поваги, пошани (часто при ввічливо-шанобливому звертанні до когось). // Пов'язаний з вираженням великої поваги, пошани до кого-небудь; побожний - 1. Який ревно виконує всі релігійні обряди; віруючий. // Властивий релігійній, віруючій людині. 2. Пов'язаний з релігією; церковний. 3. Сповнений найщирішої шани, безмежно відданий; благоговійний, шанобливий; посмертний 1. Який буває, відбувається після чиєїсь смерті (перев. для вшанування його пам'яті). // Який був опублікований або став відомим після смерті автора (про літературний твір, лист і т. ін.). // Який приходить до кого-небудь або надається комусь після смерті (про славу, визнання, звання і т. ін.). 2. Те саме, що загробний.

As it is seen from the meanings of the words in question, these adjectives are characterized by their ability to be used in different contexts as well as in various situations. In this respect of great value are those meanings which describe not only religious notions but also the matters of everyday importance (a literary piece of writing or letter being recognized after its author's death, glory and title given to somebody after his/her death as a recognition of his/her merits, achievements, etc., something done or performed in memory of and the like).

Certain situational meanings can be found in the semantics of the adjectives used in collocations земний уклін - уклін до землі як вияв 
особливої шани кому-, чому-небудь (a low bow, obeisance as an expression of special respect, regard somebody or something is treated with) and віддавати (віддати) останню шану (послугу і т. ін.); посилати останній привіт кому; проводжати в останню путь - виражати пошану до померлого, прощаючись з ним (doing homage to somebody, showing the last respects to the dead, parting, farewell words to the deceased). The adjective дорогоцінний is used in verbal communication as a form of address to express one's regards, friendliness, goodwill. Being admired, respected and excited also lead to one's appreciation of somebody or something which describe people's qualities expected in the society. For example, the lexical unit величний has three meanings, each of which characterizes the property of being admired, esteemed, worthy of respect, filled with surprise, the feeling of solemnity, something important, extraordinary, etc.: 1. Який своєю величиною, грандіозністю, силою прояву або наявністю чогось видатного, надзвичайного викликає подив, захоплення. // Який викликає почуття урочистості, піднесеності. 2. Сповнений гідності, поважності. 3. Який заслуговує пошани, поваги.

Such qualities of people as being held in respect, treated with honour, deserving recognition are closely related to the positive human traits of character, ability to reveal friendly, tactful, sincere, sympathetic, kind attitudes to others, establish kind, cordial relationships, properties of being full of joy, openness, kindness, sincerity (about voice, smile face, etc.), wellbred, hard-working, polite as well as good qualities of something which answer the required standards, volume or quantity concerning animals, plants, objects, well and vividly represented, sharp (concerning the appetite, sight, hearing, etc.). All the abovementioned meanings characterize the adjective of broad semantics добрий. It possesses 9 rather extended meanings which can be interpreted the following way: 1. Який доброзичливо, приязно, чуйно ставиться до людей; доброзичливий; протилежне лихий, поганий. // Привітний, лагідний у взаєминах. // Той, хто доброзичливо, приязно, чуйно ставиться до людей. // Який виражає доброту, щирість; сповнений ласки, приязні (про голос, усмішку, обличчя і т. ін.). 2. Для якого характерна взаємна прихильність, симпатія; близький. 3. Який приносить добро, задоволення, радість. // Корисний, потрібний, в основі якого лежить бажання добра комунебудь. // В якому виражається прихильність, співчуття, доброзичливе, шанобливе ставлення, повага до людей. // Який подобається, схвалюється; вартий наслідування. // Який свідчить про безтурботний, веселий стан людини. 4. Який має належні знання i навики для виконання чого-небудь; досвідчений. // Який користується повагою, шаною. // Розумно вихований, увічливий, працьовитий. 5. Який має 
позитивні якості або властивості, що відповідають поставленим вимогам, задовольняють їх (про предмети, тварини, рослини). // Вигідний, зручний для роботи, влаштування яких-небудь справ, заробітку. 6. Значний щодо розміру, обсягу, кількості. // Кращий від звичайного, багатий, великий, високий. // Помітно виражений, гострий (про апетит, зір, слух). // Дуже розвинений. // Значний щодо ступеня вияву, сили. 7. Гідний шани, похвали; незаплямований. 8. Те саме, що смачний. 9. Уживається для підкреслення важливості, значності кількісного визначення міри часу, простору.

Lexical semantic analysis of adjectives denoting the property of being respected in modern Ukrainian revealed their both common and distinctive features as well as peculiarities of their system and structural organization.

\section{Seme structure of adjectives in modern Ukrainian}

The study of how meaning is encoded in a language is the subject matter of semantics. It is generally assumed that its main concern is the meanings of words as lexical items. But we have to note that it is not only concerned with words as such. What is meaning? Philosophers have debated the question, with particular reference to language, for over 2000 years. No one has yet produced a satisfactory answer to it. One reason for this may be that the question, in the form in which it is posed, is unanswerable. It makes two presuppositions which are, to say the least, problematical: (a) that what we refer to, in English, with the word "meaning" has some kind of existence or reality: (b) that everything referred to as meaning is similar, if not identical, in nature. We may call these, respectively: (a) the presupposition of existence and (b) the presupposition of homogeneity. ${ }^{6}$ According to the most widely accepted theory of semantics, by meanings we mean ideas or concepts, which can be transferred from the mind of the speaker to the mind of a hearer by embodying them in the forms of one language or another. In linguistics meaning is what a language expresses about the world we live in or any possible or imaginary world ${ }^{7}$.

There are many different approaches to the way in which meaning in language is studied. Philosophers have investigated the relations between linguistic expressions, such as the words of a language and persons, things and events in the world to which these words refer. Linguists have

${ }^{6}$ Lyons J. Language and Linguistics. An Introduction. Cambridge: Cambridge University Press, 1981. P. 136.

${ }^{7}$ Longman Dictionary of Language Teaching \&Applied Linguistics. Longman Group UK Limited, 1992. P. 222. 
studied the way in which meaning in a language is structured and have distinguished between different types of meanings. The complexity of word meaning is manifold. Various attempts have been made to work out efficient procedures for the analysis and interpretation of meaning. Our lexico-semantic analysis of adjectives in modern Ukrainian presupposes the all-round study of their meanings. The latter, like the lexical units themselves, are treated as a system which is composed of hierarchically placed semes. To describe and characterize them, componential analysis is used. It is one of the contemporary methods of semantic research which is applied to the study of meaning and analyses a word into a set of meaning components or semantic features. Componential analysis provides an inventory of the semantic features encoded in lexical forms. The essential purpose of it is to identify certain general conceptual categories or semantic principles which find expression in the particular components ${ }^{8}$.

The meanings of words may be described as a combination of semantic features. The latter are classified into semantic markers by which we mean the semantic features present in the lexical meanings of other words and distinguishers - semantic features which cannot be found in the lexical meanings of other words. Furthermore, semantic markers refer to features which the word has in common with other words, whereas distinguishers refer to what differentiates or distinguishes a word from other ones. In European semantic theory the meanings are reduced to minimal components or semes, as they are called. Componential analysis proceeds from the assumption that word meaning is not an unanalyzable whole but can be decomposed into elementary semantic components, or semes. It is also assumed that these basic semantic elements can be classified into several subtypes thus ultimately constitute a highly structured system ${ }^{9}$. Different scholars suggest different terms to name this elementary constituent of meaning: semantic component, semantic features, figures of content, differential semantic elements, semantic primitive, semantic multiplier, semantic function, semantic parameter, etc. There are also such types of semes as: classeme, archeseme, differential semes, integrative semes. A distinction is also made between denotative and connotative ones. The former belong to the denotative component of meaning whereas the latter are the additional semantic components representing the connotative component of meaning. There exists the classification of semes into contextual, implicit and explicit. The structural approach to the study of semantics presupposes the use of componential analysis which bears

\footnotetext{
${ }^{8}$ Widdowson H.G. Linguistics. Oxford: Oxford University Press, 1996. P. 57.

${ }^{9}$ Sukhorolska S.M., Fedorenko O.I. Methods of Linguistic Analysis. Lviv: Publishing Centre of Ivan Franko Lviv National University, 2006. P. 116.
} 
resemblance to the mathematical process of factorizing a number, and a useful informal method of arriving at components of meaning is suggested by the analogy of arithmetical proportions ${ }^{10}$.

Componential analysis in our research is carried out on the basis of dictionary definitions (definitional analysis). In this respect the explanatory dictionary of the Ukrainian language plays a significant role in the studies of such types. It makes up an empirical basis of modern semantics as it presents the whole lexical system of the language in question. Of primary importance here are definitions of words which reveal various relations between words, when one is explained by means of the other together with their profound characteristics. Lexical meaning of the word is treated as an independent entity possessing its individual linguistic quality. The structure of each dictionary entry is conditioned by both volume and quantitative specificity of an individual lexical meaning. As a result, in dictionary definitions the lexical meanings are divided into rubrics and subrubrics.

Explanatory dictionary of the Ukrainian language is at the same time the object of linguistic study and the means of carrying out both theoretical and applied research works. It is treated as the complete fullest bank of information concerning the language under study which had been compiled taking into account the whole verbal and written products. Our research of adjectives denoting the property of being respected in modern Ukrainian is carried out on the basis of dictionary definitions by means of applying the structural approach to the study of the adjectives' lexical semantics. The procedure of dividing the lexical meanings of adjectives into semes presupposes their strict and thorough analysis. Even punctuation marks in dictionary definitions matter: comma means that the semes stand close in meaning; semi-colon denotes separation of the meaning components. Moreover, one and the same seme may form the meanings of more than one word. This quantitative characteristics of the semes forms one of the regularities of their system and structural organization. This gives grounds to consider to what extent the meanings of adjectives are related to each other.

Seme data set contains 175 definitions, among which one can find indications of positive human qualities, namely being respected, loyal, kind, sincere, well-bred, polite, recognized by other people due to his/her heroic deeds, high moral standards, everyday activities, social life, position in the society, charity, achievements in various branches of science, the feeling of responsibility, friendly attitude to all members of the society, etc.

\footnotetext{
${ }^{10}$ Fabian M. Lexical Semantics: New Approach to its Study // Journal of Interdisciplinary
} Philology 2013. № 1-2. P. 5-12. 
The whole seme data set is divided into 5 subsets: 1) positive properties of human character; 2) qualities of person's attitude towards other people; 3) the properties of being honoured, esteemed, recognized; 4) who enjoys popularity, glory, recognition due to his/her good name, authority, good reputation, renown, which (who) positively influences something, creates proper conditions for fulfilling the tasks, necessary, good for something; who acts wisely, quietly, carefully, with great caution, takes into account the interests of others; 5) contextual semes.

Semantic markers який виявляє глибоку повагу, пошану до кого-, чогонебудь, сповнений виразу глибокої поваги, який виражає пошану, гідний великої поваги, який має позитивні якості або властивості, що відповідають поставленим вимогам characterize the semantic meanings of nearly all the adjectives under study. The first subset contains the semes сповнений найщирімої поваги, шани; безмежно відданий; побожний which can be found in the semantics of the adjective благоговійний, шанобливий, добрий, святобливий; шанобливо ввічливий до людей; в якому виявляється ввічливість, уважність, люб'язність (чемний); який виявляє глибоку повагу, пошану (шанобливий); який виражає покору, смиренність (уклінний); який відзначається високими моральними якостяли, не здатний украсти, не схильний до крадіжки, який виражає правдивість, прямоту характеру, відвертість, який старанно, ретельно виконує свої обов'язки, сумлінний, який випливає з сумлінного ставлення до свойх обов'язків, зароблений без обману, своєю сумлінною прачею, який не заслуговує ніякої догани, порядний, нічим не заплямований, шановний, поважний, сповнений честі (чесний), якого поважсають, який користується повагою в кого-небудь (поважаний), який має позитивні якості або властивості, щзо відповідають поставленим вимогам, задовольняють ӥх, який приносить добро, задоволення, радість, який подобається, схвалюється, вартий наслідування, розумно вихований, увічливий, працьовитий, гідний шани (добрий), сповнений найщирімої шани, безмежно відданий, благоговійний, шанобливий (побожний), розсудливо-серйозний, розважсливий у вчинках, з позитивними якостями, поважний, сповнений гідності, поважності, який справляє позитивне враження, відзначається порядністю, пристойний, добропорядний (статечний), який має широку славу, популярність, знаменитий, добре відомий багатьом (славетний), такий, щэо має високі позитивні якості, достойний (гідний).

The second subset covers the semes which analyze the multiple ways of expressing qualities of person's attitude towards other people: який доброзичливо, приязно, чуйно ставиться до людей, доброзичливий, привітний, лагідний у взаєминах, той, хто приязно, чуйно ставиться 46 
до людей, який виражає доброту, щиирість, сповнений ласки, приязні, для якого характерна взаємна прихильність, симпатія, близький, корисний, потрібний, в основі якого лежить бажання добра кому-, чому-небудь (добрий); який діє розумно, спокійно, передбачливо, який зважає на інтереси, запити інших, виявляє повагу до них, чемний, уважний, який виявляє обережність у своӥх діях, не наражається на неприємність, небезпеку, обережний (обачний), який прославляє кого-небудь (славетний), який виявляє повагу до кого-небудь, чемний, ввічливий (поштивий, почтивий), шанобливо ввічливий у поводженні з людьми, який виражає шанобливість, увічливість (гречний). As it is seen from the research, several semes enter more than one or two subsets, and this shows close relationships between them in the system.

The third subset contains the semes revealing the properties of somebody or something who (that) deserve respect, regard, trust, authority, attention, heed, consideration, is influential, answer the demands of time, circumstances, arise surprise, admiration, wonder, the feeling of solemnity, excitement, do not tolerate objection, etc. який заслуговує помани, поваги, сповнений гідності, поважності, який своєю величиною, грандіозністю, силою прояву або наявністю чогось видатного, надзвичайного викликає подив, захоплення (величний), який користується авторитетом, впливовий, який заслуговує на повне довір'я, який не терпить, не допускає заперечень (авторитетний). пов'язаний з вираженням великої поваги, пошани до кого-небудь, гідний великої поваги (превелебний). This adjective is frequently used as a polite and respectful form of addressing somebody and as a title of bishop. To the subset under study also belong the following semes: який заслуговує поваги свойм значенням, достойнством (статечний), гідний поваги, пошани, який обирається, надається на знак поваги, пошани (почесний), якого поважають, шанують, той, кого поважають, шанують (шановний), гідний великої пошани, поваги (поштивий, почтивий, високошановний, славетний).

The words високошановний, високоповажаний, високоповажний are used as an official polite form of address or when speaking about somebody. Its synonym вельмишановний is a polite form of addressing or recollecting somebody. The meanings of lexical units вашецький, вашеський contain stylistically marked semes, on the one hand, гідний поваги, шановний and ірон. гордовитий, пихатий (ironically - haughty, disdainful), on the other. The semes який свойми діями, вчинками і т.ін. викликає почуття поваги, певної урочистості, який тримається з великою гідністю, гордовитістю characterize lexical meanings of the word величавий. Those who due to their long-lived fruitful activity deserve general acknowledgment and recognition are called маститий 
(venerable). Among distinguishers in our language material one can mention який відповідає вимогам часу, ичілком відповідний у даному випадку, потрібний (гідний), немолодий, повільний, не швидкий, протяжний, задумливий (про пісню, мелодію), великий (розміром, кількістю), який може бути прийнятий до уваги, достатній для виправдання чого-небудь, який заслуговує особливої уваги внаслідок своєї важливості, значимості (поважний), який дотримується правил пристойності (ввічливий, увічливий), зручний для чого-небудь (сприятливий), побожний (благоговійний), вигідний, зручний для роботи, влаштування яких-небудь справ, заробітку, значний щодо розміру обсягу, кількості $i$ m. ін., кращий від звичайного, багатий, великий, високий, який повністю забезпечує потребу в чому-небудь, дуже розвинений, значний щуодо ступеня вияву, сили, уживається для підкреслення важливості, значності кількісного визначення міри часу, простору (добрий), який має достаток, заможний (статечний), який вірить у бога й старанно виконує всі релігійні обряди (святобливий), шановний за святістю і релігійністю (чесний).

The fourth subset covers those semes which describe deeds, actions, activities, happenings and the like leading to something special, of good quality, positive necessary changes, respect, recognition, devotion, connected with God, religion, church, religious rituals, love, faithfulness, stability, freedom, peace, glory, nobility, popularity, big money, values, something very important, the sense of dignity, place in the society, power, business dealings and real life situations. Here belong the semes який позитивно впливає на що-небудь, створює відповідні умови для здійснення, виконання чогось (сприятливий), який приносить, приніс комусь велику славу, відомий дуже широким колам людей, який відзначається, вирізняється чимсь особливим (преславний), який ведуть, здійснюють в інтересах релігї, високий, благородний, метою якого є воля, визволення, мир, властивий релігійній, віруючій людині (побожний), який вшановує, звеличує кого-небудь (величальний), який коштує великі гроші, дуже иінний, дорогий, дуже важливий (дорогоцінний), життєвий, реальний (земний), гордий, з виразно виявленим почуттям власної гідності, який має добру якість, пов'язаний із значним службовим становищем, владою (важний), який присвятив себе чому-небудь, який, будучи пройнятий симпатією, любов'ю до когось, чогось, відзначається постійністю, вірністю (відданий). Some of the semes mentioned in the subsets are common for the lexical meanings of a rather great majority of words under study. Even their division into subsets is conventional because the semes, like lexical units, in our research are represented as open systems which can be enlarged if further studied. 
The fifth subset is made up by contextual semes which characterize the lexical meanings of the adjectives посмертний (post mortem): загробний, святий (saint): як постійний епітет до слів, пов'язаних із місиями або предметами релігійного поклоніння, освячений, уживається при вираженні переляку, подиву, обурення, праведний, непорочний, угодний богові, стосовно до великодня, почесний (honourable): честь або гідність якого не принижено, побожний (pious): який ревно виконує всі релігійні обряди, віруючий, and священний (sacred): який є предметом релігійного поклоніння, який ведуть, здійснюють в інтересах релігії, на який не можна посягати, високий, благородний, особливо почесний. All the abovementioned semes can be used in the contexts which specify the semantics of the adjectives in question. Seme in our research identifies a minimal feature of meaning, i.e. a minimal feature of the semantic structure of an adjective. Componential analysis in the present research is formalized as far as the symbolic representation of meaning components is concerned. Being applied to the study of adjectives as a definite system of the vocabulary, the componential analysis helped disclose the system and structural organization of the words in question as well as reveal their lexical and seme stock together with all their common and distinctive features.

\section{CONCLUSIONS}

Lexical semantics, especially the methods and procedures of its analysis, belongs to less investigated problems of modern linguistics. It is that system of language which is never stable, and, due to both lingual and extra - lingual factors, undergoes changes of different types. It is most sensitive to scientific and technological progress, our everyday life and activities, global world changes, etc. Despite great achievements in various branches of linguistics, still there are certain areas which are by no means complete. In the first place it concerns the structural approach to the study of lexical meaning. In the paper this problem is considered on the example of adjectives denoting the property of being respected in modern Ukrainian. The suggested approach in the present research makes up the formalized basis for the semantic classification of a certain fragment of lexis, according to which the Ukrainian language is treated as a system of definite structure, where each lexical unit occupies its definite place, and establishes various types of relationships with other ones within this system. Not only adjectives themselves are looked upon this way, but also both their meanings and semantic components. Our language material has been collected, analyzed and classified on the basis of a continuous study of the most authoritative Ukrainian explanatory dictionary. To choose 
the material of the research, we have introduced formal, purely language criterion - belonging of the lexical units to a particular part of speech the adjective. As a result, the property of being respected embraces 37 adjectives possessing 175 meanings. Taken together, they form an open-ended system of elements which are interrelated and interdependent. Nearly all the words under study are polysemantic, and their semantics is broad: from revealing the qualitative characteristics of people, their deeds, ways of life, behaviour and distinguishing features of character to describing the properties of being honoured, respected, recognized and acknowledged because of their spiritual and moral qualities. The meanings of the adjectives in question have been studied with the help of componential analysis which is considered to be of great value in contemporary linguistics. They are composed of components which, in their turn, also make up a definite system, and these components (semes) are both interrelated and interconnected. As seen from the study, they form subsets, they enter the meanings of more than one, two, etc. lexical units, undergo classifications, specify the shades of words' meanings and add additional information concerning the words' usages. By penetrating deep into the adjectives' semantics and peculiarities of their inner system and structural organization in Ukrainian, it is possible to contribute to the further study of meaning, and open new possibilities of discussing other issues of semantics which remain unsolved.

\section{SUMMARY}

The present research deals with the structural approach to the study of meaning on the material of adjectives denoting the property of being respected in modern Ukrainian. The language material is collected, analyzed and classified with the help of a continuous analysis of the Ukrainian explanatory dictionary. Both the words and their meanings are divided into groups (subsets) which contain the whole semantic characteristics of the adjectives themselves and their corresponding meaning components (semes). Each of these groups is treated as a definite system consisting of hierarchically placed elements, which occupy their definite places within the system. Polysemantic adjectives under study in many cases are synonyms which are closely interrelated and interconnected. Their semantics is broad: from revealing the qualitative characteristics of people, their deeds, ways of life, behaviour and distinguishing features of character to describing the properties of being honoured, respected, recognized and acknowledged because of their spiritual and moral qualities. Componential analysis in this paper is carried out on the basis of dictionary definitions to decompose the lexical 
meanings into semes. The procedure of dividing the lexical meanings of adjectives into semes makes it possible to classify them into certain types. Some of the semes under study characterize the meanings of more than one word. This quantitative characteristics of the semes forms one of the regularities of their system and structural organization.

\section{REFERENCES}

1. Fabian M. Lexical Semantics: New Approach to its Study // Journal of Interdisciplinary Philology 2013. № 1-2. P. 5-12.

2. Geeraerts D. Theories of Lexical Semantics. Oxford: Oxford University Press, 2010. 341 p.

3. Lipka L. English Lexicology: Lexical Structure, Word Semantics and Word-formation. Tübingen: Narr, 2002. 244 p.

4. Lyons J. Language and Linguistics. An Introduction. Cambridge: Cambridge University Press, 1981. 356 p.

5. Sukhorolska S.M., Fedorenko O.I. Methods of Linguistic Analysis. Lviv: Publishing Centre of Ivan Franko Lviv National University, 2006. $342 \mathrm{p}$.

6. Ullmann S. The Principles of Semantics. Glasgow: Jackson \& Co, Oxford: Basil Blackwell, 1957. 346 p.

7. Ullmann S. Semantics. An Introduction to the Science of Meaning. Oxford: The Alden Press Basil Blackwell, 1962. 278 p.

8. Widdowson H.G. Linguistics. Oxford: Oxford University Press, 1996. $134 \mathrm{p}$.

9. Словник української мови: В 11-ти т. Київ: Наукова думка, 1970-1980.

10. Longman Dictionary of Language Teaching \&Applied Linguistics. Longman Group UK Limited, 1992.

\section{Information about the author:}

Fabian M. P.,

Doctor of Philological Sciences in General Linguistics, Professor, Professor at the English Philology Department,

Uzhhorod National University 14, Universytetska str., Uzhhorod, 88000, Ukraine 